\title{
KEMIJSKI SASTAV FERMENTIRANE KRME POLUPRIRODNOG TRAVNJAKA SILIRANE UZ DODATAK MLJEVENOG ZRNA KUKURUZA
}

\author{
Marina Vranić, K. Bošnjak, Monika Nekić, M. Papac, Božica Lukšić, \\ Nataša Pukec Pintić, Andreja Babić, I. Vranić
}

\begin{abstract}
Sažetak
Cilj istraživanja bio je utvrditi utjecaj dodatka mljevenog zrna kukuruza biljnoj masi poluprirodnog travnjaka na $\mathrm{pH}$ vrijednost i kemijski sastav fermentirane krme.

Biljnoj masi poluprirodnog trvnjaka je kod siliranja dodano mljeveno zrno kukuruza u udjelu od 0,3, 6, 12 i $24 \%$ na 200 g biljne mase poluprirodnog travnjaka za tretmane TR0, TR3, TR6, TR12 i TR24, tim redom. Formirano je po 5 laboratorijskih silosa (5 ponavljanja) po tretmanu. Laboratorijski silosi ostavljeni su fermentirati 47 dana nakon čega je klasičnim metodama utvrđen sadržaj suhe tvari (ST) i $\mathrm{pH}$ vrijednost, a NIR spektroskopijom kemijski parametri fermentirane krme: sirovi proteini (SP), sirova vlakna (SV), pepeo, nedušićne ekstraktivne tvari (NET) i sirove masti (SM).

Utvrđeno je da dodatak $3 \%$ mljevenog zrna kukuruza biljnoj masi poluprirodnog travnjaka kod siliranja ne utječe na sadržaj ST, SP i SV, dok dodatak 3 i $6 \%$ ne utječu na sadržaj pepela, NET i pH vrijednost fermentirane krme $(\mathrm{P}>0,05)$. Dodatak 3-24 \% mljevenog zrna kukuruza biljnoj masi poluprirodnog travnjaka kod siliranja linearno povećava sadržaj ST ( $<<0,001)$, SV $(\mathrm{P}<0,001)$, NET ( $<<0,001)$, a smanjuje sadržaj $\mathrm{SP}(\mathrm{P}<0,05)$ i pepela $(\mathrm{P}<0,001)$ u fermentiranoj krmi. Zaključeno je da, od istraživanih tretmana, najveći učinak na snižavanje $\mathrm{pH}$ vrijednosti ima dodatak $12 \%$ mljevenog zrna kukuruza biljnoj masi poluprirodnog travnjaka. Osim toga, dodatak mljevenog zrna kukuruza utječe na kemijski sastav, kao preduvjet hranidbene vrijednosti fermentirane krme, na način da smanjuje sadržaj SP i pepela, a povećava sadržaj ST, SV i NET-a u fermentiranoj krmi.
\end{abstract}

Ključne riječi: kukuruz, poluprirodni travnjak, fermentirana krma, kemijski sastav

\section{Uvod}

Tijekom siliranja biljne mase, $\mathrm{u}$ silosu dolazi do fermentacije ugljikohidrata u organske kiseline koje snižavaju $\mathrm{pH}$ vrijednost biljne mase (Yang i sur., 2004.) čime sprječavaju rast i razvoj nepoželjnih aerobnih mikroorganizama poput gljivica i plijesni (Ranjit i Kung, 2000.) te nepoželjnih anaerobnih mikroorganizama poput enterobakterija i klostridija (Yang i sur., 2004.). Kvaliteta fermentacije u silosu ovisna je o dostupnom supstratu za fermentaciju te brzini postizanja anaerobnih uvjeta u silosu. U cilju povećanja kvalitete fermentacije te očuvanja hranidbene vrijednosti fermentirane krme često se, biljnoj masi kod siliranja, osobito biljnoj masi visokog pufernog kapaciteta (McDonald i sur., 1991.) dodaju aditivi (Ball i sur., 2002.).

Prof.dr.sc. Marina Vranić, izv. prof.dr.sc. Krešimir Bošnjak, corresponding autor: e-mail: kbosnjak@agr.hr, Agronomski fakultet Sveučilišta u Zagrebu, Zavod za specijalnu proizvodnju bilja, Svetošimunska cesta 25, Zagreb, Hrvatska

Monika Nekić, Mateo Papac, Božica Lukšić, student/ica na Agronomskom fakultetu Sveučilišta u Zagrebu, Zagreb, Hrvatska Nataša Pukec Pintić, Andreja Babić, Ivica Vranić, Hrvatska agencija za poljoprivredu i hranu, Poljana Križevačka 185, Križevci, Hrvatska 
Zrno kukuruza je energetsko krmivo visokog sadržaja metaboličke energije (ME) za svinje $\left(14,61 \mathrm{MJ} \mathrm{kg}^{-1} \mathrm{ST}\right)$ i za goveda $\left(12.10 \mathrm{MJ} \mathrm{kg}^{-1} \mathrm{ST}\right)$ te niskog sadržaja sirovih vlakana (SV) (20-30 $\left.\mathrm{g} \mathrm{kg}^{-1} \mathrm{ST}\right)$ te visoke probavljivosti organske tvari (OT) za svinje ( $\left.880 \mathrm{~g} \mathrm{~kg}^{-1} \mathrm{ST}\right) \mathrm{i}$ za goveda (840 $\left.\mathrm{g} \mathrm{kg}^{-1} \mathrm{ST}\right)$ (Grbeša, 2008.). Kukuruz sadrži malo ugljikohidrata topivih $\mathrm{u}$ vodi (8-11 $\left.\mathrm{g} \mathrm{kg}^{-1} \mathrm{ST}\right)$, ali je bogat izvor nestrukturnih ugljikohidrata, prvenstveno škroba (700-760 $\mathrm{g} \mathrm{kg}^{-1} \mathrm{ST}$ ) (Yang, 2005.) iz kojeg se hidrolizom oslobađaju šećeri (heksoze i pentoze) kao supstrat za fermentaciju poželjnih mikroorganizama u silosu (Muck, 1988.; Yakota i sur.,1992.).

Sitnije mljeveno zrno kukuruza, kao dodatak voluminoznoj krmi kod siliranja, smanjuje porozitet silaže i omogućava bolje sabijanje biljne mase čime pospješuje fermentaciju, sprječava respiraciju i zagrijavanje biljnog materijala (Yang, 2005.). Dodatak mljevenog zrna kukuruza, voluminoznoj krmi kod siliranja, povećava sadržaj ST silažne mase čime se stvaraju povoljni uvjeti za razvoj poželjnih mikroorganizama u silosu (Van Vuuren i sur., 1995.) te smanjuju gubitci hranjivih tvari fermentacijom i otjecanjem silažnog soka iz silosa kod siliranja krme većeg sadržaja vlage (Hibbs i sur., 1979.).

Utjecaj dodatka mljevenog zrna kukuruza voluminoznoj krmi kod siliranja, na kvalitetu fermentacije i konzerviranje hranjivih tvari, je ovisan o karakteristikama biljnog materijala te primijenjenoj tehnologiji siliranja. Dodatak kukuruza voluminoznoj krmi niskog sadržaja vodotopivih ugljikohidrata, prilikom siliranja ubrzava opadanje $\mathrm{pH}$ vrijednosti biljne mase (Sibanda i sur., 1997.; Yang i sur., 2004.) te rezultira nižom završnom pH vrijednošću i nižim sadržajem $\mathrm{NH}_{3}-\mathrm{N}$, ali većim sadržajem octene kiseline u odnosu na mliječnu kiselinu u fermentiranoj krmi (Topps i Oliver, 1993.; Sibanda i sur., 1997.).

S druge strane, dodatak mljevenog zrna kukuruza voluminoznoj krmi koja sadrži dovoljno ugljikohidrata topivih u vodi, poput travne ili travno djetelinske smjese udjela mahunarki do $30 \%$, ne utječe na kvalitetu fermentacije u silosu (Sibanda i sur., 1997.). Dodatak 5 ili 10\% mljevenog kukuruza kod siliranja travne mase i mahunarki smanjuje sadržaj neutralnih detergent vlakana (NDV) fermentirane krme s porastom udjela mahunarki u odnosu na trave u krmi (Sibanda i sur., 1997.).

S dodatkom mljevenog zrna kukuruza travnoj ili djetelinsko travnoj smjesi kod siliranja sadržaj SP ima tendenciju opadanja jer zrno kukuruza ima niži sadržaj SP u odnosu na trave i mahunarke (Moseley i Ramanathan, 1989.). Međutim, dodatak 10\% mljevenog zrna kukuruza travnoj ili travno djetelinskoj smjesi kod siliranja rezultira većim sadržajem SP fermentirane krme s porastom udjela mahunarki $(15,30 \mathrm{i} 45 \%)$ u odnosu na trave dok dodatak $5 \%$ mljevenog zrna kukuruza ne utječe na sadržaj SP fermentirane krme (Sibanda i sur., 1997.).

Biljna masa poluprirodnog travnjaka može sadržavati veći udio mahunarki ovisno o primijenjenoj agrotehnici te mikroklimatskim čimbenicima uzgoja (Knežević i sur., 2007.).

Hipoteza istraživanja je bila da će dodatak mljevenog zrna kukuruza biljnoj masi poluprirodnog travnjaka prilikom siliranja promijeniti kemijski sastav, kao preduvjet hranidbene vrijednosti fermentirane krme, te $\mathrm{pH}$ vrijednost fermentirane krme, kao pokazatelja kvalitete fermentacije u silosu. Cilj rada bio je utvrditi utjecaj dodatka mljevenog zrna kukuruza biljnoj masi poluprirodnog travnjaka na $\mathrm{pH}$ vrijednost i kemijski sastav fermentirane krme. 


\section{Materijali i metode}

\section{Pokusna površina}

Istraživanje je provedeno na pokusnim površinama Sveučilišta u Zagrebu Agronomskog fakulteta Centar za travnjaštvo smještenih na 638 metara nadmorske visine u sklopu Parka prirode Medvednica. Za potrebe istraživanja korištena je biljna masa poluprirodnog travnjaka zajednice Arrhenatheretum medioeuropaeum ruderale (Br-Bl-1919), (Hulina, 1983.). Biljna masa je izuzeta s četiri pokusne pokusne parcele dimenzija $6 \mathrm{~m} \times 2 \mathrm{~m}$ (razmak između parcela bio je $1 \mathrm{~m}$ ) na kojima je od 2004. godine primjenjivano $500 \mathrm{~kg}$ mineralnog gnojiva NPK (8:26:26) ha ${ }^{-1}$ svako proljeće $\left(0,6 \mathrm{~kg}\right.$ NPK parcelica $\left.{ }^{-1}\right)$ te $600 \mathrm{~kg} \mathrm{ha}^{-1}$ mineralnog gnojiva KAN $\left(0,72 \mathrm{~kg} \mathrm{KAN}-a\right.$ parcelica-1 ${ }^{-1}$, po $0,24 \mathrm{~kg}_{\text {parcelica }}{ }^{-1}$ na početku vegetacije, nakon 1 . otkosa i nakon 2. otkosa).

Botanički sastav tratine je utvrđen 2017. godine ručnim razdvajanjem po 200 g svježe biljne mase prvog otkosa sa svake od četiri 4 pokusne parcele. Uzorci biljne mase su razdvojeni na trave, mahunarke i korove. Utvrđeno je da se tratina sastojala od 48,72\% trava, $25,78 \%$ mahunarki i $25,50 \%$ korova.

Košnja pokusnih parcela i formiranje laboratorijskih silosa

Pokusne parcele su pokošene 16. listopada 2018. godine ručnom grebenastom kosilicom radnog zahvata $1,2 \mathrm{~m}$ po sredini svake parcelice na visinu $5 \mathrm{~cm}$ od razine tla. Iz pokošene biljne mase je izdvojeno oko $30 \mathrm{~kg}$ reprezentativne biljne mase korištene za provedbu istraživanja.

Biljna mase je silirana neposredno nakon košnje, bez provenjavanja i sjeckanja, u laboratorijske silose. Laboratorijski silosi su formirani na način da je po $200 \mathrm{~g}$ svježe biljne mase odvagnuto u PVC vrećice za vakumiranje potpuno istih dimenzija $(25 \mathrm{~cm}$ x $30 \mathrm{~cm})$. Na biljnu masu u PVC vrećicama je dodan mljeveni kukuruz, sadržaj vrećice je ručno dobro promiješan, a vrećice nakon toga zatvorene vakumiranjem pomoću aparata marke Status, model SV750.

Biljnoj masi poluprirodnog trvnjaka je kod siliranja dodano mljeveno zrno kukuruza u udjelu od 0, 3, 6, 12 i 24\% na $200 \mathrm{~g}$ biljne mase poluprirodnog travnjaka za tretmane TR0, TR3, TR6, TR12 i TR48, tim redom.

Formirano je po 5 laboratorijskih silosa ( 5 ponavljanja) po tretmanu. Laboratorijski silosi ostavljeni su fermentirati 47 dana u zatvorenom prostoru nakon čega su otvoreni i analizirani.

\section{Kemijski sastav zrna kukuruza korištenog u istraživanju}

Za potrebe istraživanja je oko $5 \mathrm{~kg}$ zrna kukuruza samljeveno na veličinu čestica $1 \mathrm{~mm}$ korištenjem mlina čekićara tvrtke Christy Noris model 11. Tijekom formiranja laboratorijskih silosa, prije početka svake razine dodavanja mljevenog zrna kukuruza, uzeta su po 2 uzorka mljevenog zrna kukuruza radi provedbe kemijskih analiza. Ukupno je analizirano 8 uzoraka mljevenog zrna kukuruza. U tablici 1 je prikazan kemijski sastav zrna kukuruza korištenog u istraživanju. 
Tablica 1. Kemijski sastav zrna kukuruza korištenog u istraživanju ( $\mathrm{g} \mathrm{kg}^{-1} \mathrm{ST}$ ako nije drugačije navedeno)

Table 1 Chemical composition of corn grain $\left(\mathrm{g} \mathrm{kg}^{-1} \mathrm{DM}\right.$ if not otherwise stated)

\begin{tabular}{|l|c|c|c|c|}
\hline \multicolumn{1}{|c|}{$\begin{array}{c}\text { Kemijski parameter } \\
\text { Chemical parameter }\end{array}$} & $\begin{array}{c}\text { Srednja vrijednost } \\
\text { Mean }\end{array}$ & Min & Max & CV (\%) \\
\hline $\begin{array}{l}\text { ST/ DM (g kg-1 fresh sample / } \\
\text { svježeg uzorka }\end{array}$ & 915,1 & 910,8 & 919,5 & 0,31 \\
\hline OT/ OM & 980,1 & 971,9 & 986,3 & 0,55 \\
\hline SP/ CP & 97,2 & 91,1 & 104,3 & 4,90 \\
\hline Škrob/Starch & 740,0 & 720,0 & 750,0 & 8,6 \\
\hline NDV/ NDF & 131,0 & 84,2 & 174,9 & 2,64 \\
\hline KDV/ ADF & 59,6 & 29,0 & 93,6 & 3,86 \\
\hline
\end{tabular}

ST, suha tvar; OT, organska tvar; SP, sirovi protein; NDV, neutralna detergent vlakna; KDV, kisela detergent vlakna $\mathrm{DM}$ - dry matter; OM - organic matter; $\mathrm{CP}$ - crude proteins; NDF - neutral detergent fibre, ADF - acid detergent fibre; CV-coefficient of variation

\section{Kemijske analize}

Nakon otvaranja laboratorijskih silosa utvrđena je pH vrijednost fermentirane biljne mase pomoću pH metra tvrtke Mettler Toledo model S220. Sadržaj ST utvrđen je sušenjem uzoraka u sušioniku s ventilatorom (EAS23-030) na temperaturi od $60^{\circ} \mathrm{C}$ tijekom 48 sati (AOAC,1990.) do konstantne mase uzorka. Osušeni uzorci su samljeveni u mlinu čekićaru tvrtke Christy Noris model 11, kroz sito otvora $1 \mathrm{~mm}$.

Kemijski sastav fermentirane krme poluprirodnog travnjaka je procijenjen NIR spektroskopijom prema normi HR-ISO No. 17025 u akreditiranom laboratoriju Centra za kontrolu kvalitete stočarskih proizvoda Hrvatske agencije za poljoprivredu i hranu u Križevcima. Korišten je NIR aparat, model DA 7200, Perten. Uzorci su prije skeniranja dosušeni min 3 sata u sušioniku na temperaturi od $105^{\circ} \mathrm{C}$, a zatim hlađeni u eksikatoru. S obzirom na prethodno utvrđen sadržaj ST, procijenjeni su slijedeći kemijski parametri hranidbene vrijednosti fermentirane krme: pepeo, sirovi proteini (SP), sirova vlakna (SV), sirove masti (SM), pepeo, i nedušićne ekstraktivne tvari (NET).

\section{Statističke analize}

Rezultati istraživanja su obrađeni korištenjem statističkog programa SAS (SAS Institut, 1999.) pomoću MIXED procedure, a kao izvor varijabilnosti koristilo se pet razina dodataka sirutke biljnoj masi poluprirodnog travnjaka prije siliranja u laboratorijskim silosima.

\section{Rezultati istraživanja i rasprava rezultata}

Prosječan sadržaj SP zrna kukuruza korištenog u istraživanju (97,2 $\left.\mathrm{g} \mathrm{kg}^{-1} \mathrm{ST}\right)$ (Tablica 1.) se uklapa u raspon sadržaja SP zrna različitih hibrida kukuruza (82-104 g kg-1 ST) (Owens i sur., 1997.). Zrno kukuruza korišteno u istraživanju je imalo visok sadržaj škroba (740 $\left.\mathrm{g} \mathrm{kg}^{-1} \mathrm{ST}\right)$, kao osnovnog ugljikohidrata i glavnog supstrata za fermentaciju u silosu, koji se uklopio u uobičajeni raspon sadržaja škroba zrna kukuruza od 700-760 $\mathrm{g} \mathrm{kg}^{-1} \mathrm{ST}$ (Yang, 2005.). 
Marina Vranić i sur.: Kemijski sastav fermentirane krme poluprirodnog travnjaka silirane uz dodatak mljevenog zrna kukuruza županije

Tablica 2. prikazuje kemijski sastav fermentirane krme poluprirodnog travnjaka silirane uz dodatak mljevenog zrna kukuruza.

Tablica 2. Kemijski sastav fermentirane krme poluprirodnog travnjaka silirane uz dodatak mljevenog zrna kukuruza (u g kg-1 ST ako nije drugačije navedeno)

Table 2 Chemical composition of fermented seminatural forage ensiled with ground corn grain supplementation (in $\mathrm{g} \mathrm{kg}^{-1} \mathrm{DM}$ if not otherwise stated)

\begin{tabular}{|l|c|c|c|c|c|c|}
\hline \multirow{2}{*}{$\begin{array}{c}\text { Istraživani } \\
\text { tretmani/ } \\
\text { Investigated } \\
\text { treatments }\end{array}$} & \multicolumn{6}{|c|}{ Kemijski parametri/Chemical parameters } \\
\cline { 2 - 7 } & $\mathrm{ST} / \mathrm{DM}$ & $\mathrm{SP} / \mathrm{CP}$ & $\mathrm{SV} / \mathrm{CF}$ & $\mathrm{NET}$ & Pepeo/Ash & $\mathrm{SM} / \mathrm{CF}$ \\
\hline TR0 & $298^{\mathrm{d}}$ & $16^{\mathrm{a}}$ & $191^{\mathrm{c}}$ & $499^{\mathrm{c}}$ & $118^{\mathrm{ab}}$ & 22,6 \\
\hline TR3 & $334^{\mathrm{d}}$ & $162^{\mathrm{ab}}$ & $199^{\mathrm{bc}}$ & $493^{\mathrm{c}}$ & $123^{\mathrm{a}}$ & 21,8 \\
\hline TR6 & $383^{\mathrm{c}}$ & $149^{\mathrm{bc}}$ & $214^{\mathrm{a}}$ & $503^{\mathrm{bc}}$ & $110^{\mathrm{bc}}$ & 22,1 \\
\hline TR12 & $433^{\mathrm{b}}$ & $149^{\mathrm{c}}$ & $211^{\mathrm{ab}}$ & $512^{\mathrm{ab}}$ & $104^{\mathrm{dc}}$ & 22,6 \\
\hline TR24 & $545^{\mathrm{a}}$ & $148^{\mathrm{c}}$ & $219^{\mathrm{a}}$ & $515^{\mathrm{a}}$ & $95^{\mathrm{d}}$ & 21,5 \\
\hline SEM & $22,5^{\mathrm{a}}$ & $6,01^{\mathrm{y}}$ & 6,95 & 5,7 & 4,7 & 0,94 \\
\hline Lin & $* * *$ & $*^{*}$ & $* * *$ & $* * *$ & $* * *$ & $\mathrm{NS}$ \\
\hline $\mathrm{Q}$ & $\mathrm{NS}$ & $*$ & $\mathrm{NS}$ & $\mathrm{NS}$ & $\mathrm{NS}$ & $\mathrm{NS}$ \\
\hline
\end{tabular}

TR0, TR3, TR6, TR12, TR24, biljna masa poluprirodnog travnjaka silirana uz dodatak mljevenog zrna kukuruza 0, 3, 6, 12 i 24\%, tim redom; ST, suha tvar ( $\mathrm{g} \mathrm{kg}^{-1}$ svježeg uzorka); SP, sirovi proteini; SV, sirova vlakna; NET, nedušićne ekstraktivne tvari; SM, sirova mast; SEM, standardna greška srednje vrijednosti; Lin, linearni utjecaj dodatka mljevenog zrna kukuruza; Q, kvadratni utjecaj dodatka mljevenog zrna kukuruza; ${ }^{a, b, c, d}$ vrijednosti u istom stupcu označene različitim slovima se statistički značajno razlikuju * $\mathrm{P}<0,05, * * * \mathrm{P}<0,001$.

TR0, TR3, TR6, TR12, TR24, semi-natural grassland forage ensiled with ground corn grain supplementation of $0,3,6$, 12 and $24 \%$ in that order; DM, dry matter ( $\mathrm{g} \mathrm{kg}^{-1}$ fresh sample); CP, crude proteini; SV, crude fiber; NET, non-nitrogen extractive substances; CF, crude fat; SEM, standard error of the mean; Lin, the linear effect of the ground corn grain supplementation; Q, the quadratic effect of the ground corn grain supplementation; ${ }^{\mathrm{a}, \mathrm{b}, \mathrm{c}, \mathrm{d}}$ values in the same column marked with different letters differ significantlly $* \mathrm{P}<0.05$, *** $\mathrm{P}<0,001$.

Sadržaj ST fermentirane krme ukazuje na kvalitetu fermentacije u silosu te razinu konzerviranja hranjivih tvari, ali i na potencijalnu konzumaciju krme i proizvodnost životinja (Chamberlain i Wilkinson, 1996.). Naime, sadržaj ST voluminozne krme je proporcionalan konzumaciji ST, pa hranidba krmom većeg sadržaja ST rezultira većom konzumacijom ST kao najvažnijom varijablom o kojoj ovisi proizvodnost životinja (Cushnahan i Gordon, 1995.). Optimalan sadržaj ST fermentirane biljne mase (300 - $400 \mathrm{~g} \mathrm{ST} \mathrm{kg}^{-1}$ svježeg uzorka) se postiže umjerenim provenjavanjem biljne mase prije siliranja radi povećanja koncentracije vodotopivih ugljikohidrata u ST krme te sprječavanja gubitaka hranjivih tvari otjecanjem silažnog soka iz silosa (Zimmer i Wilkins, 1984; O’Kiely i Muck, 1998.). Biljna masa koja je prije siliranja previše provenuta (>450 $\mathrm{g} \mathrm{ST} \mathrm{kg}^{-1}$ svježeg usjeva) se teško sabija u silosu pa dolazi do većih gubitaka hranjiva respiracijom i proteolizom (Chamberlain i Wilkinson, 1996; Hashemzadeh-Cigari i sur., 2011.). Svi istraživani tretmani hranidbene vrijednosti fermentirane biljne mase poluprirodnog travnjaka (tablica 2.) su imali veći sadržaj ST od $250 \mathrm{~g} \mathrm{~kg}^{-1}$ svježeg uzorka sadržaja ST ispod kojeg 
se mogu očekivati gubitci hranjivih tvari ocjeđivanjem silažnog soka iz silosa (Van Vuuren i sur., 1995.). S povećanjem razine dodatka mljevenog zrna kukuruza biljnoj masi poluprirodnog travnjaka kod siliranja vidljivo je linearno povećanje sadržaja ST fermentirane krme $(\mathrm{P}<0,01)$ (tablica 2.) što je u suglasju s ranijim istraživanjima (Van Vuuren i sur., 1995). Suho zrno kukuruza ima visok sadržaj ST (>840 $\mathrm{g} \mathrm{kg}^{-1}$ svježeg uzorka), pa njegov dodatak, voluminoznoj krmi kod siliranja, povećava sadržaj ST silažne mase čime se stvaraju povoljni uvjeti za razvoj poželjnih mikroorganizama u silosu (Van Vuuren i sur., 1995.).

Visok sadržaj sirovih proteina (SP) povezuje se s krmivima visokog sadržaja energije (Mäntysaari i sur. 2004; Vranić i sur., 2020.). Sadržaj SP se u idealnoj fermentiranoj travnoj masi kreće od 150 - $175 \mathrm{~g} \mathrm{~kg}^{-1} \mathrm{ST}$ (Chamberlain i Wilkinson, 1996.) u koje vrijednosti se uklapaju tretmani TR1 i TR2 dok su tretmani TR3, TR4 i TR5 obzirom na sadržaj SP malo ispod granice idealne fermentirane travne mase (tablica 2.). Utvrđen je kvadratni utjecaj dodatka mljevenog zrna kukuruza biljnoj masi kod siliranja na sadržaj SP $(\mathrm{P}<0,05)$. Utvrđeno linearno opadanje sadržaja SP s povećanjem udjela kukuruza $(\mathrm{P}<0,05)$ je u suglasju s ranijim istraživanjima da dodatak krmiva niskog sadržaja SP, poput mljevenog zrna kukuruza, voluminoznoj krmi kod siliranja rezultira nižim sadržajem SP smjese krmiva nakon fermentacije (Moseley i Ramanathan, 1989.).

U fermentiranoj biljnoj masi, vlakna su kao strukturni ugljikohidrati glavni izvor energije (Phipps i sur., 2000.). Sadržaj vlakana u krmi je u pozitivnoj korelaciji s duljinom probavljanja hrane, a u negativnoj korelaciji s konzumacijom i probavljivošću krme (Vranić i sur., 2020.). Veći sadržaj vlakana u krmi rezultira nižim sadržajem dostupne energije iz krme u probavnom traktu. Dodatak 3\% mljevenog zrna kukuruza biljnoj masi poluprirodnog travnjaka kod siliranja (TR3) nije utjecao na sadržaj SV fermentirane krme, dok su tretmani TR6, TR12 i TR24 imali isti sadržaj SV koji je bio veći u odnosu na tretman TR0 (tablica 2). Utvrđeno je linearno povećanje sadržaja vlakana $\mathrm{u}$ fermentiranoj biljnoj masi s povećanjem dodatka mljevenog zrna kukuruza biljnoj masi kod siliranja $(\mathrm{P}<0,001)$. U ranijim istraživanjima utjecaja dodatka mljevenog zrna kukuruza biljnoj masi na kemijski sastav fermentirane krme je korištena biljna masa trava košena u fenološkoj fazi pune cvatnje i djetelina košenih u fenološkoj fazi sredine cvatnje prvog otkosa kada su trave, odnosno smjese trava i mahunarki nakon fermentacije bez dodatka kukuruza imale visok sadržaj NDV (635-688 g NDV kg-1 ST), a sadržaj SP 111-127 g kg-1 ST te je utvrđeno da dodatak mljevenog zrna kukuruza biljnoj masi kod siliranja snižava sadržaj vlakana u fermentiranoj krmi (Sibanda i sur., 1997.).

U ovom istraživanju je korišten 3. otkos biljne mase poluprirodnog travnjaka koji je bio visoke hranjivosti (169 g SP u TR0) i niskog sadržaja SV (191 g SV kg-1 ST nakon fermentacije, TR0) približno jednakom sadržaju SV zrna kukuruza u ovom istraživanju, pa je dodatak mljevenog zrna kukuruza rezultirao povećanjem sadržaja SV u fermentiranoj krmi.

Dodatak 3\% (TR3) i 6\% (TR6) mljevenog zrna kukuruza biljnoj masi poluprirodnog travnjaka nije utjecao na sadržaj NET-a, odnosno sadržaj topivih ugljikohidrata u fermentiranoj krmi, u odnosu na TR0 (tablica 2.), ali je s povećanjem dodatka mljevenog zrna kukuruza utvrđeno linearno povećanje NET-a u fermentiranoj krmi $(\mathrm{P}<0,001)$. Zrno kukuruza je bogato škrobom.

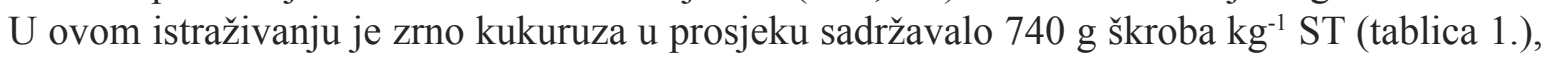
pa se s povećanjem dodatka mljevenog zrna kukuruza biljnoj masi kod siliranja povećavao sadržaj škroba odnosno NET-a u fermentiranoj krmi. 
Pepeo je izvor minerala i nema energetsku vrijednost, a njegov veći sadržaj u biljnom materijalu ukazuje na moguću kontaminaciju krme česticama tla i drugim nečistoćama ili patvorenje krmiva (Chamberlain i Wilkinson, 1996.). Veći sadržaj pepela smanjuje konzumaciju krme, probavljivost vlakana te apsorpciju pojedinih minerala u gastrointestinalom traktu životinja (Khan i sur., 2007; Vranić i sur., 2008.).

Dodatak 3\% (TR3) i 6\% (TR6) mljevenog zrna kukuruza biljnoj masi poluprirodnog travnjaka kod siliranja nije utjecao na sadržaj pepela dok je dodatak 12\% (TR4) i 24\% (TR5) smanjio sadržaj pepela u fermentiranoj krmi (tablica 2$)$. Utvrđeno je linearno opadanje $(\mathrm{P}<0,001)$ sadržaja pepela u fermentiranoj krmi poluprirodnog travnjaka s dodatkom mljevenog zrna kukuruza biljnoj masi prije siliranja (tablica 2.).

Niže razine dodatka mljevenog zrna kukuruza biljnoj masi kod siliranja (5 ili 10\%) također nisu utjecale na sadržaj pepela u fermentiranoj krmi (Sibanda i sur., 1997.).

Svi istraživani tretmani su imali $\mathrm{pH}$ vrijednosti veće od $\mathrm{pH} 4,2$ kao kritične $\mathrm{pH}$ vrijednosti fermentirane biljne mase koja omogućuje konzerviranje fermentirane krme bez kvarenja (McDonald, 1981.). U grafikonu 1 su prikazane $\mathrm{pH}$ vrijednosti fermentirane krme istraživanih tretmana.

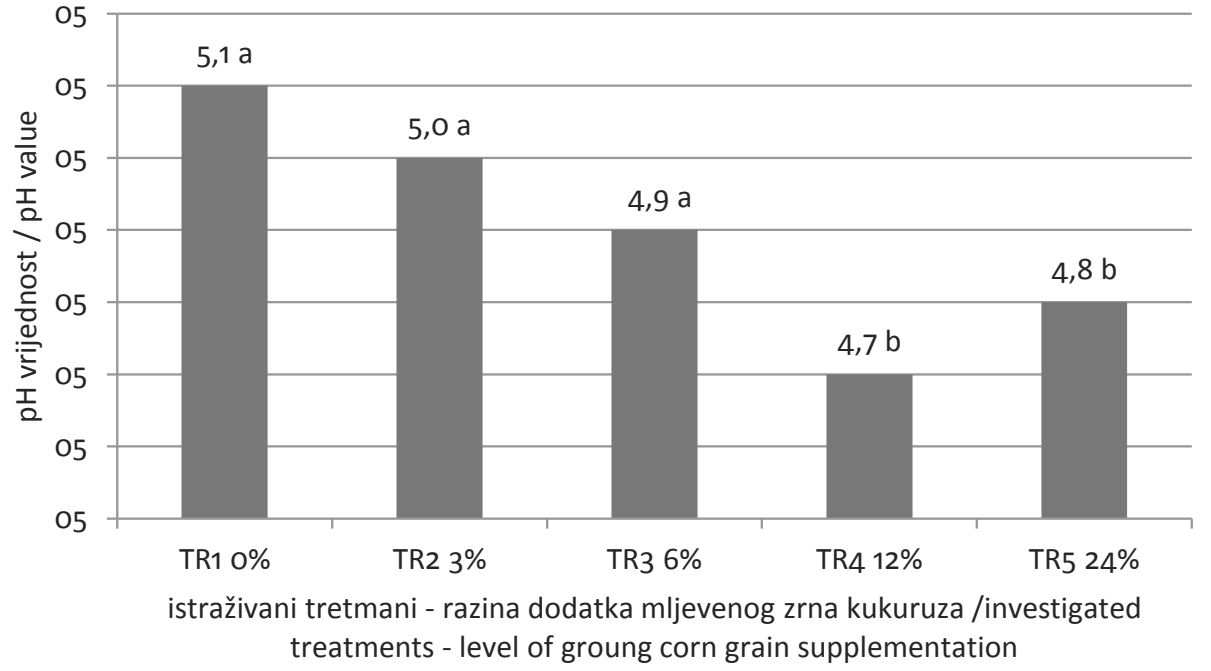

Grafikon 1. Utjecaj dodatka mljevenog zrna kukuruza biljnoj masi na pH vrijednost fermentirane krme

Graph 1 The effect of ground corn supplementation on $\mathrm{pH}$ value of fermented forage

Poželjna pH vrijednost travne silaže ili sjenaže poželjne kvalitete fermentacije se kreće u rasponu $\mathrm{pH}$ vrijednosti od $\mathrm{pH}$ 4,0 do $\mathrm{pH} 4,5$ (Chamberlain i Wilkinson, 1996.) u koje vrijednosti se ne uklapaju $\mathrm{pH}$ vrijednosti fermentirane krme utvrđene u ovom istraživanju (grafikon 1.). Dodatak 3\% (TR3) i 6\% (TR6) zrna kukuruza biljnoj masi kod siliranja nije utjecao na završnu pH vrijednost fermentirane krme dok je dodatak 12\% (TR4) i 24\% (TR5) mljevenog zrna kukuruza rezultirao nižom pH vrijednošću u odnosu na TR0, TR3 i TR6. Kod siliranja biljne mase većeg sadržaja ST je teže postići anaerobne uvjete u silosu te se stabilizira kod veće pH vrijednosti (Leibensperger and Pitt, 1988.). Iako se sa većim sadržajem mljevenog zrna kukuruza, kao dodatka biljnoj masi kod siliranja, linearno povećavao sadržaj ST fermentirane 
krme utvrđeno je da su veće razine dodatka mljevenog zrna kukuruza (12 i 24\%) rezultirale nižim pH vrijednostima fermentirane krme. Naime, dodatak sitnije mljevenog zrna kukuruza voluminoznoj krmi kod siliranja smanjuje porozitet silažne mase i omogućava bolje sabijanje krme čime doprinosi poželjnoj fermentaciji, sprječava respiraciju i zagrijavanje biljnog materijala (Yang, 2005.). Osim toga, veći sadržaj mljevenog zrna kukuruza rezultirao je i većim sadržajem škroba u silosu kao supstrata za fermentaciju koji pospješuje formiranje kiselina i opadanje $\mathrm{pH}$ vrijednosti u silosu (Yang, 2005.). U ranijem istraživanju je viša razina mljevenog zrna kukuruza (10\%) biljnoj masi kod siliranja rezultirala nižom pH vrijednošću fermentirane krme radi većeg sadržaja mliječne kiseline u usporedbi s nižom razinom dodatka mljevenog zrna kukuruza (5\%) (Sibanda i sur., 1997.).

\section{Zaključak}

Zaključeno je da, od istraživanih tretmana, najveći učinak na snižavanje $\mathrm{pH}$ vrijednosti ima dodatak $12 \%$ mljevenog zrna kukuruza biljnoj masi poluprirodnog travnjaka. Osim toga, dodatak mljevenog zrna kukuruza utječe na kemijski sastav, kao preduvjeta hranidbene vrijednosti fermentirane krme, na način da smanjuje sadržaj SP i pepela, a povećava sadržaj ST, SV i NET-a u fermentiranoj krmi.

\section{LITERATURA}

1. AOAC (1990.): Official methods of the association of analytical chemists, Vol. 2, $15^{\text {th }}$ Edition. AOAC, Arlington, Virginia, USA.

2. Ball D.M., Hoveland C.S., Lacefield G.D. (2002.): Southern Forages. Third edition. Published by the Potash \& Phosphate Institute (PPI), Georgia, USA.

3. Chamberlain A.T., Wilkinson J.M. (1996.): Feeding the Dairy Cow. Chalcombe Publication, PainShall, Ln2 3LT. UK.

4. Cushnahan A., Gordon F.J. (1995.): The effects of grass preservation on intake, apparent digestibility and rumen degradation characteristics. Animal Science, 60, 429-438.

5. Grbeša D. (2008.): Bc hibridi kukuruza u hranidbi životinja. Bc Institut za oplemenjivanje i proizvodnju bilja d.d., Zagreb

6. Hashemzadeh-Cigari F., Khorvash M., Ghorbani G. R., Taghizadeh A. (2011.): The effects of wilting, molasses and inoculants on the fermentation quality and nutritive value of lucerne silage. South African Journal of Animal Science, 41, 4: 377-388.

7. Hibbs J. W., Conrad H. R., Van Keuren R.W. (1979.): Effects of different forages and methods of feeding concentrate on dry matter intake and milk production in dairy cows fed complete diets. Ohio Agric. Res. Dev. Ctr. Res. Cir. No. 248.

8. Hulina N. (1983.): Fitocenološko-tipološka istraživanja travnjaka objekta "Fakultetski majur". Poljoprivredna znanstvena smotra-ACS, 62, 403-418.

9. Khan Z.I., Ashraf M., Hussain A. (2007.): Evaluation of Macro Mineral Contents of Forages: Influence of Pasture and Seasonal Variation. Asian-Australasian Journal of Animal Science, 20, 6: 908-913.

10. Knežević M., Leto J., Perčulija G., Bošnjak K., Vranić M. (2007.): Effects of liquid manure application on yield, quality and botanical composition of grassland. Cereal Research Communications, 35, 2: 637-640.

11. Leibensperger R.Y., Pitt R.E. (1988.): Modelling the effects of formic acid and molasses on ensilage. Journal of Dairy Science, 71, 1220-1231. 
Marina Vranić i sur.: Kemijski sastav fermentirane krme poluprirodnog travnjaka silirane uz dodatak mljevenog zrna kukuruza županije

12. Mäntysaari P., Huhtanen P., Nousiainen J., Virkki M. (2004.): The effect of concentrate crude protein content and feeding strategy of total mixed ration on performance of primiparous dairy cows. Livestock Production Science, 85 (2-3), 223-233.

13. McDonald P. (1981.): The Biochemistry of Silage. Wiley, Chichester. p. 226.

14. McDonald P., Henderson A.R., Heron S.J.E. (1991.): The Biochemistry of Silage. $2^{\text {nd }}$ ed. Chalcombe Publ, Bucks., England.

15. Moseley G., Ramanathan V. (1989.): The effects of dry feed additives on the nutritional value of silage. Grass and Forage Science, 44, 391-397.

16. Muck R.E. (1988.): Factors influencing silage quality and their implications for management. Journal of Dairy Science, 71: 2992-3002.

17. O’Kiely P., Muck R.E. (1998.): Grass silage. In: Cherney, J.H., Cherney, D.J.R. (eds)

18. Owens F.N., Secrist D.S., Hill W.J., Gill D.R. (1997.): The effect of grain source and grain processing on performance of feedlot cattle: A review. Journal of Animal Science, 75, 868-879.

19. Phipps R.H., Sutton J.D., Beever D.E., Jones A.K. (2000.): The effect of crop potential and the limitations. Australian Journal of the Experimental Agriculture, 38, 697-706.

20. Ranjit N.K., Kung L. (2000.): The effect of Lactobacillus buchheri, Lactobacillus plantarum or a chemical preservative on the fermentation and aerobic stability of corn silage. Journal of Dairy Science, 83, 526535.

21. SAS (1999.): SAS ${ }^{\circledR}$ Software, SAS Institute Inc., Cary, North Carolina, USA.

22. Sibanda S.R., Jingura M., Topps J.H. (1997.): The effect of level of inclusion of the legume Desmodium uncinatum and the use of molasses or ground maize as additives on the chemical composition of grass- and maize-legume silages. Animal Feed Science and Technology, 68, 295-305

23. Topps J.H., Oliver J. (1993.): Animal foods of Central Africa. Zimbabwe Agriculture Journal, Harare, 154.

24. Van Vuuren A.M., Huhtanen P., Dulphy J.P. (1995.): Improving the feeding value of ensiled forages. In: Joumet, M., Grenet, E., Farce, M.-H., Thierez, M., Dermaquilly, C. (Eds.), Recent Developments in the Nutrition of Herbivores. Proceedings of the Fourth International Symposium on the Nutrition of Herbivores. IRNA Editions, Paris, 279-307.

25. Vranić M., Knežević M., Perčulija G., Matić I., Turčin D. (2008.): Utjecaj dodatka kukuruzne silaže travnoj silaži različitih rokova košnje na ad libitum konzumaciju obroka. Mljekarstvo, 58 (1): 69-84.

26. Vranić M., Bošnjak K., Rukavina I., Glavanović S., Pintić Pukec N., Babić A., Vranić I. (2020.): Procjena kemijskog sastava voluminozne krme NIR spektroskopijom. Journal of Central European Agriculture, 21, 3: 554-568.

27. Yakota H., Kim J. H., Okajima T., Ohshima M. (1992.): Nutritional quality of wilted Napier grass ensiled with or without molasses. Asian-Australasian Journal of Animal Science, 5, 673-676.

28. Yang C.M.J., Huang S.C., Chang T., Cheng Y.H., Chang C.T. (2004.): Fermentation acids, aerobic fungal growth, and intake of napiergrass ensiled with nonfiber carbohydrates. Journal of Dairy Sciences, $87,630-636$.

29. Yang C.M.J. (2005.): Proteolysis, Fermentation Efficiency, and In Vitro Ruminal Digestion of Peanut Stover Ensiled with Raw or Heated Corn, Journal of Dairy Sciences, 88, 8: 2903-2910.

30. Zimmer E., Wilkins R.J. (1984.): Efficiency of silage systems: a comparison between unwilted and wilted silages. Eurowilt. Sonderheft 69. Institute of Grassland and Forage Research, Braunschweig-Volkenrode, Germany. 


\title{
CHEMICAL COMPOSITION OF FERMENTED SEMINATURAL FORAGE ENSILED WITH GROUND CORN SUPPLEMENTATION
}

\begin{abstract}
Summary
The objective of this paper was to determine the effect of ground corn grain supplementation to the semi-natural grassland on the $\mathrm{pH}$ value and chemical composition of fermented forage. The ground corn was supplemeted to fresh semi-natural grassland forage at ratio of $0,3,6,12$ and $24 \%$ for treatments TR1, TR2, TR3, TR4 and TR5 respectivelly. A total of 25 laboratory siloses (5 treatments x 5 repetitions) per treatment were formed. Forage was fermented for 47 days before analysis by wet chemistry for dry matter (DM) content and $\mathrm{pH}$ value while NIR spectroscopy was used for the chemical quality parameters prediction: crude proteins $(\mathrm{CP})$, crude fiber $(\mathrm{CF})$, ash, non-nitrogen extractive substances (NET) and crude fat $(\mathrm{CF})$. It was found that the addition of $3 \%$ of ground maize grain to the semi-natural grassland forage at ensiling does not affect $\mathrm{DM}, \mathrm{CP}$ and $\mathrm{CF}$, while the addition of 3 and $6 \%$ does not affect the ash content, NET and $\mathrm{pH}$ value of fermented forage ( $\mathrm{P}>0.05)$. The addition of $3-24 \%$ of ground corn to the semi-natural grassland forage at ensiling linearly increased the DM $(\mathrm{P}<001), \mathrm{CF}(\mathrm{P}<0,001), \mathrm{NET}$ $(\mathrm{P}<0,001)$ and at the same time reduced $\mathrm{CP}(\mathrm{P}<0.05)$ and ash $(\mathrm{P}<0,001)$ in fermented forage. It was concluded that, of the treatments investigated, the greatest effect on lowering the $\mathrm{pH}$ value in silo had $12 \%$ supplementation of ground corn to the semi-natural forage. Besides, the ground corn supplementation affected the chemical composition, as a prerequisite of forage nutritive value, in a way that it reduced the content of $\mathrm{CP}$ and ash, and increased DM, CF and NET in fermented forage.
\end{abstract}

Keywords: corn, semi-natural grassland, fermented forage, chemical composition

Primljeno: 31.08.2021.

Prihvaćeno: 28.09.2021. 